\title{
PENERAPAN MODEL PEMBELAJARAN KOOPERATIF TIPE LEARNING TOGETHER (LT) DIKOMBINASIKAN DENGAN DRILL AND PRACTICE UNTUK MENINGKATKAN SIKAP ILMIAH DAN HASIL BELAJAR SISWA PADA MATERI POKOK LARUTAN PENYANGGA KELAS XI MIPA 3 SMA NEGERI 2 SUKOHARJO TAHUN PELAJARAN 2016/2017
}

\author{
Nur Latifah Ayu Kurniawati ${ }^{\star}$, Elfi Susanti VH, dan Ashadi \\ Program Studi Pendidikan Kimia, FKIP, Universitas Sebelas Maret, Surakarta, Indonesia \\ *Keperluan Korespondensi, HP: 085702604824, e-mail: nlatifah_ayuk@rocketmail.com
}

\begin{abstract}
ABSTRAK
Penelitian ini bertujuan untuk meningkatkan: (1) sikap ilmiah (2) hasil belajar siswa pada materi pokok larutan penyangga kelas XI MIPA 3 SMA Negeri 2 Sukoharjo dengan menerapkan model pembelajaran Learning Together (LT) dikombinasikan dengan drill and practice. Penelitian ini merupakan penelitian tindakan kelas (PTK) yang dilaksanakan dalam dua siklus. Setiap siklus terdiri atas tahap perencanaan, tindakan, pelaksanaan, dan refleksi. Subjek penelitian ini yaitu siswa kelas XI MIPA 3 SMA N 2 Sukoharjo tahun pelajaran 2016/2017. Sumber data penelitian berasal dari siswa dan guru. Teknik pengumpulan data berupa tes dan non tes. Analisis data menggunakan teknik analisis deskriptif kualitatif. Hasil penelitian menunjukkan bahwa: (1) model pembelajaran LT dikombinasikan dengan drill and practice dapat meningkatkan sikap ilmiah siswa pada materi larutan penyangga kelas XI MIPA 3 SMA Negeri 2 Sukoharjo tahun pelajaran 2016/2017. Tingkat ketercapaian kriteria sikap ilmiah sebesar 44,11\% dan meningkat pada siklus I menjadi 67,65\% dan siklus II sebesar 85,29\%; (2) model pembelajaran LT dikombinasikan dengan drill and practice dapat meningkatkan hasil belajar siswa pada materi larutan penyangga kelas XI MIPA 3 SMA Negeri 2 Sukoharjo tahun pelajaran 2016/2017. Tingkat ketercapaian hasil belajar siswa sebesar $50 \%$ pada siklus I dan menjadi $85,29 \%$ pada siklus II.
\end{abstract}

Kata Kunci : Learning Together, drill and practice, sikap ilmiah, hasil belajar, larutan penyangga

\section{PENDAHULUAN}

Pendidikan merupaka faktor penting dalam menentukan kemajuan bangsa. Pasal 1 angka 1 UU No.20 tahun 2003 menyatakan bahwa pen-didikan adalah usaha sadar dan terencana untuk mewujudkan suasana belajar dan proses pembelajaran agar peserta didik secara aktif mengem-bangkan potensi dirinya untuk memiliki kekuatan spiritual keagamaan, pengen-dalian diri, kepribadian, kecerdasan, akhlak mulia, serta ketrampilan yang diperlukan dirinya, masyarakat, bangsa dan Negara. Tujuan pendidikan nasional yang tercantum pada UU No.20 tahun 2003 adalah untuk berkembangnya potensi peserta didik agar menjadi manusia yang beriman dan bertakwa kepada Tuhan Yang Maha Esa, berakhlak mulia, sehat, berilmu, cakap, kreatif, mandiri, dan menjadi warga Negara yang demokratis serta bertanggung jawab [1]. Dalam rangka mencapai tujuan tersebut, pemerintah terus melakukan berbagai upaya perombakan dalam berbagai komponen sistem pendidikan nasional, salah satunya yaitu dengan mengembangkan komponen kurikulum yang telah diberlakukan pada saat ini yaitu kurikulum 2013.

Kurikulum 2013 adalah sebuah kurikulum yang dikembangkan untuk meningkatkan dan menyeimbangkan kemampuan soft skills dan hard skills yang berupa sikap, ketrampilan, dan pengetahuan [2]. Penerapan kurikulum 2013 lebih menekankan pada pencapaian 3 kompetensi, yaitu sikap, pengetahuan, dan ketrampilan. Ketiga kompetensi tersebut diharapkan dapat 
berjalan seimbang dan beriringan sehingga pembelajaran yang dilaksanakan dapat berhasil dengan maksimal. Pelaksanakan pembelajaran harus memperhatikan beberapa hal agar tujuan tersebut tercapai, di antaranya: orientasi pembelajaran berpusat pada peserta didik; mengembangkan kreati-vitas dari peserta didik; menciptakan kondisi yang menyenangkan dan me-nantang; bermuatan nilai, etika, esetika, logika, dan kinestetika; serta menyedi-akan pengalaman belajar yang bera-gam melalui penerapan berbagai stra-tegi, model, dan metode pembelajaran yang menyenangkan, kontekstual, efektif, efisien, dan bermakna.

Kimia merupakan salah satu mata pelajaran wajib yang diajarkan pada peserta didik Sekolah Menengah Atas (SMA) program MIPA. Mata pelajaran tersebut seringkali dianggap sebagai mata pelajaran yang sulit bagi peserta didik. Kesulitan peserta didik dalam mempelajari ilmu kimia dimung-kinkan berasal dari kesulitan dalam memahami istilah dan konsep kimia ataupun kesulitan dalam perhitungan matematika. Guru kimia diharapkan da-pat menyajikan mata pelajaran kimia semenarik mungkin untuk mengatasi kesulitan para peserta didik.

Berdasarkan hasil observasi selama Program Pengalaman Lapangan (PPL) tentang pembelajaran kimia di SMA Negeri 2 Sukoharjo telah menerapkan kurikulum 2013 untuk menunjang pembelajaran, namun dalam pelaksanaannya belum sesuai dengan yang dikehendaki. Orientasi pembelajaran masih berpusat pada guru (teacher centered) dan guru juga masih menggunakan metode konvensional dalam pelaksanaan pembelajaran. Kondisi tersebut membuktikan bahwa penerapan kurikulum 2013 di SMA N 2 Sukoharjo berjalan kurang maksimal, khususnya pada pembelajaran kimia.

SMA N 2 Sukoharjo menetapkan Kriteria Ketuntasan Minimal (KKM) untuk mata pelajaran kimia khusunya kelas XI MIPA tahun pelajaran 2016/2017 sebesar 75. Berdasarkan wawancara dengan guru kimia kelas XI, salah satu materi pelajaran yang sulit yaitu materi larutan penyangga. Hal tersebut dapat dilihat dari data hasil ketuntasan nilai ulangan harian siswa selama 3 tahun terakhir pada Tabel 1.

Tabel 1. Hasil Ketuntasan Ulangan Harian Siswa Materi Pokok Larutan Penyangga Kelas XI MIPA SMA N 2 Sukoharjo

\begin{tabular}{cccc}
\hline & & \multicolumn{2}{c}{ Ketuntasan (\%) } \\
\cline { 3 - 4 } Kelas & KKM $2014 /$ & $2015 /$ \\
& & 2015 & 2016 \\
\hline XI MIPA 1 & 70 & 32,43 & 14,85 \\
XI MIPA 2 & 70 & 47,06 & 23,67 \\
XI MIPA 3 & 70 & 37,14 & 21,53 \\
\hline
\end{tabular}

(Sumber : Daftar Nilai Ulangan Harian Siswa XI MIPA SMA N 2 Sukoharjo)

Materi pokok larutan penyangga memiliki beberapa karakteristik seperti materi tersebut bersifat abstrak pada bagian reaksi asam basa, memerlukan pemahaman konsep pada bagian sifat larutan penyangga, dan bersifat aplikatif pada bagian fungsi larutan penyangga. Model pembelajaran yang menarik diperlukan agar siswa merasa mudah untuk menerima dan memahami materi pelajaran tersebut. Model pem-belajaran yang diterapkan diusahakan sesuai dengan karakteristik siswa dan karakteristik materi yang akan disampaikan. Guru diharapkan mampu mengatur strategi dalam setiap proses pembelajaran yang dilakukan dengan penerapan model pembelajaran.

Berdasarkan kajian dokumen nilai Ulangan Akhir Sekolah (UAS) semester satu, didapatkan hasil ketuntasan siswa kelas XI MIPA 3 sebesar 20,59\% dan rata-rata nilai UAS sebesar 65,514 . Hasil tersebut masih berada di bawah kriteria ketuntasan minimal mata pela-jaran kimia yaitu 75 . Hal tersebut mengindikasikan bahwa hasil belajar siswa kelas XI MIPA 3 masih tergolong rendah, sehingga perlu dilakukan perbai-kan pada proses pembelajaran kimia.

Berdasarkan hasil wawancara dan pengamatan pada saat melakukan observasi, ditemukan beberapa permasalahan yang mempengaruhi hasil belajar siswa dalam mata pelajaran kimia kelas XI MIPA SMA N 2 Sukoharjo yai-tu 
sikap pasif siswa pada proses pembelajaran dan minat membaca siswa yang masih tergolong rendah. Permasalahan lain yang ditemukan adalah sikap ilmiah siswa yang masih tergolong rendah yang dapat diketahui dari rasa ingin tahu dan sikap berpikir kritis yang rendah terhadap pelajaran kimia.

Berkaitan dengan hal tersebut, maka diperlukan suatu tindakan seba-gai upaya untuk meningkatkan kualitas proses pembelajaran kimia di SMA N 2 Sukoharjo khususnya kelas XI MIPA 3. Salah satu upaya yang dapat ditempuh adalah dengan menerapkan model pembelajaran yang menarik dan mam-pu meningkatkan sikap ilmiah siswa un-tuk membantu siswa dalam mengatasi kesulitan belajar. Tindakan tersebut dapat dilakukan melalui suatu Penelitian Tindakan Kelas (PTK) yang bertujuan untuk memperbaiki kualitas proses pembelajaran sehingga dapat memperbaiki hasil belajar siswa [3].

Salah satu model pembelajaran yang dapat diterapkan dalam pembelajaran kimia yaitu model pembelajaran kooperatif yang dapat mendorong sis-wa untuk berinteraksi secara aktif dan positif dalam kelompok. Terdapat bebe-rapa macam tipe dari model pembela-jaran kooperatif, salah satunya yaitu ti-pe learning together (LT). LT merupa-kan suatu tipe model pembelajaran kooperatif yang menekankan pada kerjasama kelompok dalam mencapai tujuan pembelajaran [4].

Dalam meningkatkan keterampilan siswa mengenai materi perhitungan pada mata pelajaran kimia terkhusus larutan penyangga, maka penerapan pembelajaran dengan LT perlu dikombinasikan dengan model lain yang dapat menunjang ketrampilan tersebut. Model tersebut adalah drill and practice, suatu model yang menerapkan kegiatan latihan - latihan atau pengulangan sehingga dapat meningkatkan keterampilan tertentu, dimana dalam konteks ini yaitu ketrampilan menghitung [5].

Berdasarkan uraian yang dikemukakan di atas, maka penelitian menerapkan model pembelajaran kooperatif tipe Learning Together (LT) dikombinasikan dengan Drill And Practice untuk meningkatkan sikap ilmiah dan hasil belajar siswa pada materi pokok larutan penyangga kelas XI MIPA 3 SMA Negeri 2 Sukoharjo Tahun Pelajaran 2016/2017.

\section{METODE PENELITIAN}

Penelitian ini dilaksanakan dikelas XI MIPA 3 SMA Negeri 2 Sukoharjo yang beralamatkan di Jalan Raya SoloKartasura, Mendungan, Pa-belan, Kartasura, Sukoharjo. Penelitian ini merupakan Penelitian Tindakan Ke-las (PTK) yang dilaksanakan dengan dua siklus. Masing-masing siklus terdiri dari 4 tahapan yaitu, tahap perencana-an tindakan, pelaksanaan tindakan, observasi, dan refleksi [6]. Subjek penelitian adalah siswa kelas XI MIPA 3 SMA Negeri 2 Sukoharjo Tahun Pelajaran 2016/2017. Sumber data berasal dari guru dan siswa.

Teknik pengumpulan data yang digunakan berupa tes dan non-tes (angket, wawancara, observasi, dan kajian dokumen). Teknik analisis data yang digunakan adalah analisis kualitatif. Teknik analisis kualitatif meliputi tiga komponen, yaitu reduksi data, penyaji-an data, penarikan kesimpulan dan verifikasi data [7]. Teknik triangulasi metode digunakan untuk menguji validitas data dalam penelitian. Teknik tersebut dilakukan dengan membandingkan informasi atau data dengan cara yang berbeda melalui metode observasi, wawancara, dan kajian dokumen [8].

\section{HASIL DAN PEMBAHASAN}

Berdasarkan hasil identifikasi pratindakan menyatakan bahwa kelas XI MIPA 3 mengalami permasalahan dalam rendahnya sikap ilmiah dan hasil belajar, oleh karena itu diperlukan per-baikan dan peningkatan kualitas proses pembelajaran melalui penerapan model pembelajaran LT dikombinasikan dengan drill and practice dalam Penelitian Tindakan Kelas (PTK).

Kegiatan pembelajaran pada penelitian ini diawali dengan apersepsi, orientasi dan motivasi yang disampaikan oleh guru (Fase 1). Kegiatan inti pembe- 
lajaran dimulai dengan siswa memperhatikan penjelasan garis besar materi pembelajaran larutan penyangga yang disajikan oleh guru. Siswa diberikan kesempatan untuk bertanya setelah memperhatikan penjelasan dari guru (Fase 2). Siswa membentuk kelompok secara heterogen dengan bimbingan guru (Fase 3). Siswa diberikan latihan soal terkait materi larutan penyangga (Fase 4), selanjutnya siswa mengerjakan soal lanjutan (Fase 5). Setiap kelompok menerima lembar kerja diskusi mengenai materi larutan penyangga (Fase 6). Siswa mengerjakan soal diskusi secara berkelompok dan setiap anggota kelompok memberikan sumbangan kemampuannya untuk menyelesaikan permasalahan yang diberikan (Fase 7). Siswa menarik suatu kesimpulan dari jawaban diskusi kelompok mengenai materi larutan penyangga. Setiap perwakilan kelompok diberikan kesempatan untuk mempresentasikan hasil diskusi secara lisan di depan kelas, sedangkan siswa yang belum memperoleh giliran presentasi menuliskan ringkasan dari hasil diskusi yang melakukan presentasi (Fase 8). Kegiatan pembelajaran diakhiri dengan siswa dan guru menyimpulkan bersama-sama hasil diskusi yang telah dilakukan.

\section{Siklus I}

\section{a. Perencanaan Tindakan}

Perencanaan tindakan dilakukan dengan mempertimbangkan strategi pembelajaran dan menyusun instrumen penelitian yang terdiri dari instrumen pembelajaran dan penilaian. Instrumen pembelajaran meliputi silabus dan RPP, sedangkan instrumen penilaian meliputi penilaian aspek pengetahuan, sikap, keterampilan, dan sikap ilmiah siswa. Peneliti dan guru melakukan kajian terhadap silabus yang telah ditetapkan oleh sekolah sesuai kurikulum 2013 dalam pembuatan instrumen pembelajaran.

Penerapan model pembelajaran Learning Together dikombinasikan dengan drill and practice didukung dengan adanya kelompok. Pembentukan kelom- pok diskusi dilakukan dengan mempertimbangkan keheterogenitasan siswa. Jumlah siswa kelas XI MIPA 3 SMA Negeri 2 Sukoharjo tahun pelajaran 2016/2017 sebanyak 34 siswa. Berdasarkan jumlah siswa tersebut, maka dilakukan pembagian menjadi 8 kelompok. Penelitian ini dilaksanakan secara kolaboratif antara guru dan peneliti serta dibantu dengan observer yang lain guna mencatat dan mengamati segala kegiatan yang dilakukan siswa selama kegiatan pembelajaran pada lembar observasi yang telah disediakan.

\section{b. Pelaksanaan Tindakan}

Pelaksanaan tindakan dimulai pada tanggal 27 Februari 2016 dan berakhir pada 10 Maret 2017. Pelaksanaan tindakan dilakukan selama 8 jam pelajaran (4 kali pertemuan), terdiri dari $6 \mathrm{x}$ 45 menit untuk penyampaian materi larutan penyangga dan $2 \times 45$ menit untuk kegiatan evaluasi. Kegiatan pada pertemuan pertama dilaksanakan di laboratorium Kimia sedangkan pertemuan kedua dan ketiga dilaksanakan di ruang kelas. Kegiatan evaluasi pembelajaran dilaksanakan pada pertemuan keempat. Kegiatan tersebut meliputi penilaian aspek pengetahuan dimana siswa harus menjawab soal ulangan dalam bentuk pilihan ganda sebanyak 15 butir. Waktu yang tersisa digunakan untuk mengisi angket penilaian diri.

\section{c. Observasi Tindakan}

Observasi tindakan dilaksana-kan selama kegiatan pembelajaran pertemuan pertama hingga kegiatan evaluasi pada siklus I. Observer dan guru mengamati berlangsungnya kegiatan pembelajaran dengan cermat. Keseluruhan siswa mengikuti pembelajaran dengan baik. Siswa masih belum terbiasa dengan penerapan model pembelajaran LT dikombinasikan dengan drill and practice pada pertemuan pertama. Hal tersebut dapat dilihat dengan keengganan siswa mengerjakan soal-soal latihan secara individu. Siswa sudah mulai terbiasa dengan model pembelajaran yang diterapkan pada pertemuan selanjutnya. Siswa terlihat antusias dalam kegiatan 
diskusi walaupun ada beberapa anggota kelompok yang terlihat pasif. Antusias dan rasa ingin tahu siswa mulai meningkat. Hal tersebut dapat dilihat ketika kegiatan diskusi, banyak siswa yang memperhatikan ketika ada teman yang presentasi serta mengerjakan latihanlatihan soal.

Hasil penilaian analisis hasil belajar siswa pada siklus I aspek pengetahuan dapat dilihat pada Tabel 2. Berdasarkan hasil tes pengetahuan da-pat diketahui bahwa hasil belajar pada aspek pengetahuan belum mencapai target ketuntasan yang ditentukan, dimana targetnya sebesar $70 \%$.

Tabel 2. Ketuntasan Hasil Belajar Aspek Pengetahuan

\begin{tabular}{ccc}
\hline Kategori & $\begin{array}{c}\text { Jumlah } \\
\text { Siswa }\end{array}$ & $\begin{array}{c}\text { Ketuntasan } \\
(\%)\end{array}$ \\
\hline Tuntas & 17 & 50 \\
Tidak Tuntas & 17 & 50 \\
\hline
\end{tabular}

Hasil capaian ketuntasan belajar dari tiap soal dan tiap indikator kompetensi soal disajikan dalam Tabel 3.

Tabel 3. Hasil Analisis Tes Aspek Pengetahuan Siklus I

\begin{tabular}{cccccc}
\hline \multirow{2}{*}{ IK } & \multirow{2}{*}{$\begin{array}{c}\text { No. } \\
\text { Soal }\end{array}$} & Tar & \multicolumn{2}{c}{$\begin{array}{c}\text { Ketercapaian } \\
\text { get }\end{array}$} & \\
\cline { 4 - 5 } & & & Soal & Indktr & \\
\hline IK 1 & 1 & 70 & 73,53 & 73,5 & Tuntas \\
IK 2 & 2 & 70 & 67,65 & 55,9 & Belum \\
& 3 & & 52,94 & & Tuntas \\
IK 3 & 4 & 70 & 47,06 & 47,1 & Belum \\
IK 4 & 5 & 70 & 76,47 & 76,5 & Tuntas \\
& 6 & & 50,00 & & \\
& 7 & & 85,29 & & \\
& 8 & & 50,00 & & Belum \\
IK 5 & 9 & 70 & 67,65 & 67,6 & Tuntas \\
& 10 & & 91,18 & & \\
& 11 & & 82,35 & & \\
& 12 & & 44,12 & & \\
IK 6 & 13 & 70 & 70,59 & 70,6 & Tuntas \\
IK 7 & 14 & 70 & 91,18 & 91,2 & Tuntas \\
\hline
\end{tabular}

Berdasarkan data di atas, masih terdapat tiga indikator kompetensi yang belum tuntas dari 7 indikator. Indikator kompetensi tersebut yaitu IK 1 , IK 2, dan
IK 3. Butir soal nomor 3 pada IK 2 (membedakan larutan penyangga dan bukan penyangga) belum tuntas dikarenakan siswa masih belum memahami konsep dasar larutan penyangga. Pada soal nomor 3 siswa diharapkan mampu mengidentifikasi pasangan larutan a-sam dan basa yang membentuk larutan penyangga, namun masih banyak siswa yang belum bisa mengidentifikasi jenis larutan yang termasuk ke dalam larutan penyangga. Butir soal nomor 4 pada IK 3 (mengidentifikasi komponen larutan penyangga) belum tuntas dikarenakan siswa masih belum memahami komponen penyusun larutan penyangga. Pada soal nomor 4 siswa diharapkan mampu mengidentifikasi larutan dengan komponen penyusunnya yang termasuk ke dalam larutan penyangga, namun masih banyak siswa yang belum memahami komponen penyusun dari larutan penyangga. Butir soal pada nomor $6,8,9$ dan 12 pada IK 3 (menghitung nilai $\mathrm{pH}$ atau $\mathrm{pOH}$ larutan penyangga) belum tuntas dikarenakan siswa masih bingung untuk mengaplikasikan rumus dalam menger-jakan soal. Hal lain yang menyebabkan siswa belum tuntas dalam aspek penge-tahuan yaitu karena siswa kurang fokus dalam kegiatan pembelajaran dan kurang berani untuk menanyakan materi yang belum dipahami.

Berdasarkan analisis hasil penilaian aspek sikap siklus I dapat diketa-hui bahwa siswa yang mencapai ketun-tasan sebanyak 27 siswa dari 34 siswa atau $79,41 \%$ sedangkan siswa yang belum tuntas yaitu 7 siswa atau 20,59\%. Presentase ketuntasan tersebut telah mencapai target yang ditentukan yaitu sebesar $75 \%$. Hasil capaian ketuntasan penilaian sikap dari tiap aspek berdasarkan analisis triangulasi data disajikan dalam Tabel 4. Berdasarkan analisis indikator pada aspek sikap, terdapat satu dari 4 indikator yang belum mencapai target, yaitu sikap percaya diri. Ketidaktercapaian pada sikap percaya diri dikarenakan siswa masih kurang percaya diri untuk ikut andil dalam diskusi 
kelompok. Hal tersebut terlihat dengan aktivitas beberapa siswa yang cenderung pasif dalam kelompok seperti malu dalam mengutarakan pendapatnya dan dalam presentasi.

Tabel 4. Hasil Penilaian Aspek Sikap Siklus I

\begin{tabular}{cccl}
\hline $\begin{array}{c}\text { Aspek } \\
\text { Sikap }\end{array}$ & $\begin{array}{c}\text { Target } \\
(\%)\end{array}$ & $\begin{array}{c}\text { Ketercapaian } \\
(\%)\end{array}$ & Kriteria \\
\hline Spiritual & 75 & 94,12 & Tuntas \\
Percaya & 75 & 70,59 & Belum \\
Diri & 75 & 85,29 & Tuntas \\
Disiplin & 75 Tus \\
$\begin{array}{c}\text { Tanggung } \\
\text { Jawab }\end{array}$ & 75 & 82,35 & Tuntas \\
\hline
\end{tabular}

Hasil ketercapaian penilaian tiap aspek keterampilan dapat dilihat dalam Tabel 3.

Tabel 3. Hasil Ketercapaian Aspek Keterampilan Siklus I

\begin{tabular}{cccc}
\hline $\begin{array}{c}\text { Aspek } \\
\text { keterampilan }\end{array}$ & $\begin{array}{c}\text { Target } \\
(\%)\end{array}$ & $\begin{array}{c}\text { Ketercapa } \\
\text { ian (\%) }\end{array}$ & Kriteria \\
\hline Praktikum & 75 & 100 & Tuntas \\
Laporan & 75 & 100 & Tuntas \\
\hline
\end{tabular}

Berdasarkan hasil penilaian as-pek keterampilan menunjukkan bahwa kedua aspek penilaian keterampilan te-lah melebihi target yang ditentukan. Ketercapaian ketuntasan tersebut menandakan bahwa siswa telah memiliki keterampilan dalam melakukan percobaan dan menyusun laporannya.

Berdasarkan analisis hasil penilaian aspek sikap ilmiah dapat diketahui bahwa siswa yang mencapai ketuntasan sebanyak 23 siswa dari 34 siswa atau $67,65 \%$ sedangkan siswa yang belum tuntas yaitu 11 siswa atau 32,35\%. Presentase ketuntasan tersebut belum mencapai target yang ditentukan, dimana target ketuntasan yang telah ditentukan yaitu sebesar $75 \%$. Hasil capaian ketuntasan penilaian sikap dari tiap aspek berdasarkan analisis triangulasi data disajikan dalam Tabel 5 . Berdasarkan analisis indikator pada aspek sikap ilmiah, masih terdapat tiga dari empat indikator yang belum mencapai target. Aspek sikap ilmiah tersebut yaitu rasa ingin tahu, respek terhadap data, dan berpikir kritis. Hal tersebut terlihat pada aktivitas siwa yang kurang antusias dalam proses pembelajaran seperti tidak memperhatikan guru dalam menerangkan pelajaran dan siswa lain yang sedang presentasi. Siswa juga cenderung pasif pada saat diskusi seperti tidak memberikan tanggapan terhadap hasil diskusi yang diperoleh. Ketidaktercapaian target tersebut menandakan bahwa sikap ilmiah siswa masih tergolong rendah.

Tabel 5. Hasil Observasi Sikap IImiah Siswa Siklus I

\begin{tabular}{|c|c|c|c|}
\hline $\begin{array}{l}\text { Indikator } \\
\text { Sikap }\end{array}$ & $\begin{array}{c}\text { Target } \\
(\%)\end{array}$ & $\begin{array}{l}\text { Keterca- } \\
\text { paian(\%) }\end{array}$ & Kriteria \\
\hline $\begin{array}{l}\text { Rasa ingin } \\
\text { tahu }\end{array}$ & 75 & 61,76 & $\begin{array}{l}\text { Belum } \\
\text { tuntas }\end{array}$ \\
\hline $\begin{array}{l}\text { Respek } \\
\text { terhadap data }\end{array}$ & 75 & 70,59 & $\begin{array}{l}\text { Belum } \\
\text { tuntas }\end{array}$ \\
\hline Berpikir kritis & 75 & 67,65 & $\begin{array}{l}\text { Belum } \\
\text { tuntas }\end{array}$ \\
\hline $\begin{array}{l}\text { Berpikiran } \\
\text { terbuka dan } \\
\text { kerjasama }\end{array}$ & 75 & 85,29 & Tuntas \\
\hline
\end{tabular}

\section{d. Refleksi Tindakan}

Berdasarkan observasi tindakan siklus I dapat diketahui bahwa terdapat tiga aspek penilaian yang belum mencapai target yang ditentukan, sehingga diperlukan perbaikan dan peningkatan kualitas pembelajaran pada siklus II. Aspek tersebut meliputi aspek pengetahuan, aspek sikap, dan aspek sikap ilmiah. Aspek keterampilan tidak perlu dilakukan lagi pada siklus II dikarenakan telah mencapai target yang ditentukan.

\section{Siklus II}

\section{a. Perencanaan Tindakan}

Peneliti bersama dengan guru berdiskusi untuk merencanakan tindakan lanjutan pada siklus II. Kesepakat-an diskusi yang diperoleh yaitu siklus II dilaksanakan sebanyak 2 kali pertemuan, pertemuan pertama untuk menyampaikan materi dan pertemuan kedua untuk evaluasi hasil belajar siklus II. Penyampaian materi difokuskan pada indikator kompetensi yang belum tercapai target ketuntasan, yakni pada indikator membedakan larutan penyangga dan 
bukan penyangga, identifikasi komponen larutan penyangga, dan menghitung nilai $\mathrm{pH}$ atau $\mathrm{pOH}$ larutan penyangga.

Penyempurnaan serta perbaikan terhadap kendala-kendala yang terdapat pada siklus I merupakan fokus dari tindakan pada siklus II. Guru menekankan siswa untuk banyak berlatih soal dan aktif bertanya jika masih terdapat kesulitan. Peneliti membuat instrumen pembelajaran berupa RPP siklus II. Instrumen RPP meliputi 3 indikator yang belum tuntas pada siklus I. Peneliti hanya menyusun instrumen untuk tes aspek pengetahuan siklus II untuk instrumen penilaian. Instrumen angket sikap dan sikap ilmiah yang digunakan pada siklus II sama halnya pada siklus I.

Pengubahan jumlah kelompok dilakukan pada siklus II. Jumlah kelompok dibentuk dari 8 kelompok pada siklus I menjadi 10 kelompok pada sik-lus II. Setiap kelompok terdiri dari $3-4$ orang. Pengurangan kelompok dilaku-kan dengan tujuan agar suasana dalam diskusi dapat kondusif. Penentuan anggota kelompok didasarkan pada hasil belajar siswa aspek pengetahuan pada siklus I.

\section{b. Pelaksanaan Tindakan}

Pertemuan pertama siklus II dilaksanakan pada tanggal 13 Maret 2017. Pertemuan pada siklus II sama halnya dengan pertemuan pada siklus I yaitu dengan menerapkan model pembelajaran Learning Together dikombinasikan dengan Drill and Practice. Kegiatan pembelajaran pada pertemuan pertama yaitu membahas materi yang belum dikuasai siswa berdasarkan hasil refleksi pada siklus I. Sintaks kegiatan pembelajaran di siklus II sama halnya dengan siklus I, akantetapi pembelajaran lebih difokuskan pada materi pembelajaran yang belum tuntas pada tes pengetahuan siklus I.

Pertemuan kedua dilaksanakan pada tanggal 17 Maret 2017. Kegiatan pada pertemuan kedua yaitu evaluasi hasil belajar siklus II yang sama dengan evaluasi hasil belajar pada siklus I. Evaluasi meliputi teknik tes dan non tes. Teknik tes berupa soal pilihan ganda sejumlah 10 butir, sedangkan non tes berupa pengisian angket penilaian diri aspek sikap dan sikap ilmiah siswa.

\section{c. Observasi Tindakan}

Siswa terlihat sangat antusias dan berperan aktif dalam melakukan kegiatan diskusi pada kegiatan pembelajaran siklus II. Siswa lebih berani mengemukakan pendapat dan terlibat aktif dalam diskusi kelompok. Siswa yang terlihat telah memahami materi larutan penyangga membantu anggota kelompoknya yang belum paham materi tersebut. Siswa saling bertukar pikiran dalam mengerjakan soal diskusi. Guru berperan sebagai fasilitator dalam kegiatan diskusi ataupun presentasi serta memberikan konfirmasi untuk mencegah terjadinya miskonsepsi pada proses pembelajaran.

Hasil penilaian analisis hasil belajar siswa pada siklus II aspek pengetahuan dapat dilihat pada Tabel 6. Berdasarkan analisis hasil tes siklus II aspek pengetahuan dapat disimpulkan bahwa semua indikator kompetensi pada materi larutan penyangga telah mencapai target yang ditentukan.

Tabel 6. Ketuntasan Hasil Belajar Aspek Pengetahuan

\begin{tabular}{ccc}
\hline Kategori & $\begin{array}{c}\text { Jumlah } \\
\text { Siswa }\end{array}$ & $\begin{array}{c}\text { Ketuntasan } \\
(\%)\end{array}$ \\
\hline Tuntas & 29 & 85,29 \\
Tidak Tuntas & 5 & 14,71 \\
\hline
\end{tabular}

Hasil capaian ketuntasan belajar dari tiap soal dan tiap indikator kompetensi soal disajikan dalam Tabel 7.

Tabel 7. Hasil Analisis Tes Aspek Pengetahuan Siklus II

\begin{tabular}{|c|c|c|c|c|c|}
\hline \multirow[t]{2}{*}{ IK } & \multirow{2}{*}{$\begin{array}{c}\text { No. } \\
\text { Soa } \\
\text { I }\end{array}$} & \multirow{2}{*}{$\begin{array}{l}\text { Tar } \\
\text { get }\end{array}$} & \multicolumn{2}{|c|}{$\begin{array}{c}\text { Ketercapaian } \\
(\%)\end{array}$} & \multirow[t]{2}{*}{ Kriteria } \\
\hline & & & Soal & Iktr & \\
\hline $\mathrm{IK} 1$ & 1 & 70 & 97,1 & 97,1 & Tuntas \\
\hline IK 2 & $\begin{array}{l}2 \\
3\end{array}$ & 70 & $\begin{array}{l}91,2 \\
85,3\end{array}$ & 88,2 & Tuntas \\
\hline IK 3 & 4 & 70 & 91,2 & 91,2 & Tuntas \\
\hline IK 4 & $\begin{array}{l}5 \\
6\end{array}$ & 70 & $\begin{array}{l}100 \\
97,1\end{array}$ & 100 & Tuntas \\
\hline IK 5 & $\begin{array}{l}7 \\
8 \\
9\end{array}$ & 70 & $\begin{array}{l}82,5 \\
29,4 \\
94,1\end{array}$ & 75,7 & Tuntas \\
\hline IK 6 & 10 & 70 & 88,2 & 88,2 & Tuntas \\
\hline
\end{tabular}


Berdasarkan analisis hasil penilaian aspek sikap siklus II dapat diketahui bahwa siswa yang mencapai ketuntasan sebanyak 30 siswa dari 34 siswa atau $88,24 \%$ sedangkan siswa yang belum tuntas yaitu 4 siswa atau $11,77 \%$. Presentase ketuntasan tersebut telah mencapai target yang ditentukan, dimana target ketuntasan yang telah ditentukan yaitu sebesar $75 \%$. Hasil capaian ketuntasan penilaian sikap dari tiap aspek berdasarkan analisis triangulasi data disajikan dalam Tabel 8.

Tabel 8. Hasil Penilaian Aspek Sikap Siklus I

\begin{tabular}{cccc}
\hline $\begin{array}{c}\text { Aspek } \\
\text { Sikap }\end{array}$ & $\begin{array}{c}\text { Target } \\
(\%)\end{array}$ & $\begin{array}{c}\text { Keterca- } \\
\text { paian } \\
(\%)\end{array}$ & Kriteria \\
\hline Spiritual & 75 & 100 & Tuntas \\
Percaya & 75 & 85,29 & Tuntas \\
Diri & 75 & 91,18 & Tuntas \\
$\begin{array}{c}\text { Disiplin } \\
\text { Tanggung } \\
\text { Jawab }\end{array}$ & 75 & 91,18 & Tuntas \\
\hline
\end{tabular}

Berdasarkan analisis hasil penilaian aspek sikap sikap ilmiah siklus II dapat diketahui bahwa siswa yang mencapai ketuntasan sebanyak 29 siswa dari 34 siswa atau 85,29\% sedangkan siswa yang belum tuntas yaitu 5 siswa atau $14,71 \%$. Presentase ketuntasan tersebut telah mencapai target yang ditentukan yaitu sebesar $75 \%$. Hasil capaian ketuntasan peni-laian sikap dari tiap aspek berdasarkan analisis triangulasi data disajikan dalam Tabel 9.

Tabel 9. Hasil Observasi Sikap IImiah Siswa Siklus II

\begin{tabular}{cccc}
\hline $\begin{array}{c}\text { Indikator } \\
\text { Sikap }\end{array}$ & $\begin{array}{c}\text { Target } \\
(\%)\end{array}$ & $\begin{array}{c}\text { Keterca- } \\
\text { paian (\%) }\end{array}$ & Kriteria \\
\hline $\begin{array}{c}\text { Rasa ingin } \\
\text { tahu }\end{array}$ & 75 & 82,35 & Tuntas \\
$\begin{array}{c}\text { Respek } \\
\text { terhadap data } \\
\text { Berpikir kritis } \\
\text { Berpikiran } \\
\text { terbuka dan } \\
\text { kerjasama }\end{array}$ & 75 & 88,24 & Tuntas \\
\hline
\end{tabular}

\section{d. Refleksi Tindakan}

Berdasarkan analisis hasil penialaian pada siklus II menunjukkan bahwa keseluruhan aspek meliputi aspek pengetahuan, aspek sikap, aspek sikap ilmiah telah mengalami peningkat-an hasil capaian dan sudah melampaui target yang ditentukan sehingga penelitian di akhiri pada siklus II.

Berdasarkan hasil ketercapaian penilaian ketiga aspek menunjukkan bahwa kegiatan pembelajaran dengan model Learning Together dikombinasikan dengan drill and practice pada materi larutan penyangga dapat me-ningkatkan sikap ilmiah dan hasil belajar siswa.

\section{Perbandingan Antar Siklus}

Perbandingan hasil tindakan antarsiklus digunakan untuk mengeta-hui peningkatan yang terjadi selama tindakan siklus I dan siklus II. Perbandingan hasil tindakan antara siklus I dan II disajikan dalam Tabel 10.

Tabel 10. Perbandingan Hasil Siklus I dan Siklus II Materi Larutan Penyangga Kelas XI MIPA3 SMA N 2 Sukoharjo Tahun Pelajaran 2016/2017

\begin{tabular}{ccc}
\hline \multirow{2}{*}{ Aspek } & \multicolumn{2}{c}{ Ketercapaian (\%) } \\
\cline { 2 - 3 } & Siklus I & Siklus II \\
\hline Pengetahuan & 50,00 & 85,29 \\
Sikap & 79,41 & 88,24 \\
Keterampilan & 100 & - \\
Sikap IImiah & 67,65 & 85,29 \\
\hline
\end{tabular}

Semua aspek telah mencapai target yang ditentukan pada pembelajaran siklus I dan siklus II. Berdasarkan hasil tersebut dapat dinyatakan bahwa kegiatan pembelajaran dengan menerapkan model LT dikombinasikan dengan drill and practice dalam pembelajaran kimia materi larutan penyangga di kelas XI MIPA 3 SMA N 2 Sukoharjo Tahun Pelajaran 2016/2017 telah berhasil dilakukan. Hal tersebut ditandai dengan kualitas proses yaitu sikap ilmiah dan kualitas hasil yang meliputi aspek pengetahuan, aspek sikap, dan aspek keterampilan yang diukur telah mengalami peningkatan dari siklus I ke siklus II

Hal ini sejalan dengan penelitian sebelumnya, yakni pembelajaran meng- 
gunakan model Learning Together lebih efektif dalam meningkatkan hasil belajar siswa [9]. Penerapan model pembelajaran ini juga berdampak positif dimana siswa dapat temotivasi untuk lebih percaya diri dalam menyampaikan pendapat atau mengajukan pertanyaan satu sama lain guna memahami materi yang sedang dipelajari. Adanya kombinasi drill and practice dengan model LT seja-lan dengan teori Gagne dimana pembelajaran lebih ditekankan pada proses penerimaan materi untuk mencapai hasil belajar.

Penerapan model pembelajaran LT menunjang terjadinya peningkatan sikap ilmiah siswa. Implikasi dari penerapan model LT yaitu siswa dituntut untuk berinteraksi dengan lingkungan-nya seperti bekerja sama dengan kelompok dibawah bimbingan guru dalam pemecahan masalah. Siswa yang semula pasif menjadi lebih aktif dalam berkontribusi pada kegiatan diskusi. Siswa menjadi lebih antusias selama proses pembelajaran dan lebih berani dalam menyatakan dan memberikan tanggapan selama kegiatan diskusi berlangsung.

\section{KESIMPULAN}

Berdasarkan hasil penelitian dapat disimpulkan bahwa penerapan model pembelajaran Learning Together dikombinasikan dengan drill and practice pada materi larutan penyangga kelas XI MIPA3 SMA Negeri 2 Sukoharjo tahun pelajaran 2016/2017 dapat meningkatkan sikap ilmiah dan hasil belajar siswa. Hal tersebut dapat dilihat pada uji pratindakan sebanyak 44,11\% siswa dalam kategori sikap ilmi-ah tinggi, pada siklus I meningkat men-jadi $67,65 \%$ siswa memiliki kategori sikap ilmiah tinggi, dan pada siklus II meningkat lagi menjadi $85,29 \%$ siswa memiliki kategori sikap ilmiah tinggi. Hasil belajar siswa aspek pengetahuan siklus I sebesar $50 \%$, meningkat menjadi $85,29 \%$ pada siklus II Sedangkan hasil belajar aspek sikap sosial dan spiritual sebesar $79,41 \%$ pada siklus I menjadi $88,24 \%$ pada siklus II.

\section{UCAPAN TERIMA KASIH}

Penulis mengucapkan terima-kasih kepada Dra. Dwi Ari Listiyani, M.Pd., selaku kepala sekolah SMA $\mathrm{N} 2$ Sukoharjo yang telah memberikan izin untuk melaksanakan penelitian serta kepada Sri Martini R, S.Pd., selaku guru mata pelajaran kimia yang telah mengizinkan penulis menggunakan kelasnya untuk penelitian di SMA N 2 Sukoharjo.

\section{DAFTAR RUJUKAN}

[1] Departemen Pendidikan dan kebudayaan. (2003). UndangUndang Nomor 20 Tahun 2003 tentang Sistem pendidikan Nasional. Jakarta: Departemen Pendidikan dan Kebudayaan.

[2] Fadlillah, M. (2014). ImplementasiKurikulum 2013 dalam Pembelajaran SD/MI, SMP/MTs, \& SMA/MA. Yogyakarta: Ar-Ruzz Media

[3] Suyadi. (2012). Panduan Penelitian Tindakan Kelas. Yogyakarta: DIVA Press.

[4] Slavin, Robert E. (2008). Psikologi Pendidikan: Teori dan Praktik. Jakarta : PT indeks

[5] Anitah, Sri. (2009). Teknologi Pembelajaran. Surakarta: Yuma Pustaka

[6] Kusumah, W \& Dwitagama, D. (2010). Mengenal Penelitian Tindakan Kelas. Jakarta: PT Indeks

[7] Daryanto. (2009). Panduan Proses Pembelajaran Kreatif \& Inovatif. Jakarta: AV Publisher

[8] Arifin, Zainal. (2012). Penelitian Pendidikan: Metode dan Paradigma Baru. Bandung: PT Remaja Rosdakarya

[9] Bukunola, J \& Idown, D. (2012). British Journal of Education. 2(3), 307-325. 